\title{
Designing the dragon or does the dragon design? An analysis of the impact of creative industries on urban development of Beijing
}

\author{
Erwin van Tuijl* \\ Department of Regional, Port and Transport Economics \& \\ European Institute for Comparative Urban Research (Euricur), \\ Erasmus University Rotterdam, \\ P.O. Box 1738, \\ 3000 DR Rotterdam, The Netherlands \\ Email: vantuijl@ese.eur.nl \\ *Corresponding author

\section{Jan van der Borg} \\ Department of Economics, \\ Ca' Foscari University of Venice, \\ Cannaregio 873, Fondamenta S.Giobbe, \\ 30121 Venezia, Italy \\ and \\ Department of Regional, Port and Transport Economics \& \\ European Institute for Comparative Urban Research (Euricur), \\ Erasmus University Rotterdam, \\ P.O. Box 1738, \\ 3000 DR Rotterdam, The Netherlands \\ Email: vdborg@unive.it
}

\begin{abstract}
Inspired by work on the creative class and creative cities, cities in Europe and Northern America have started to invest in creativity in general and in design in particular. Much less is known about the role of creativity in emerging economies. This paper analyses the role of design in the socioeconomic development of Beijing. We identify main success factors and barriers for design businesses and show how design can be used for socioeconomic development. Backed up by state investments and fast decision making, neighbourhoods have been revitalised and modern iconic landmarks are added to the collection of old monuments. Moreover, priority has changed from 'Made in China' to 'Created in China', allowing the country's industries to move upwards in the value chain. Nevertheless, and despite of the presence of key research institutes, further developments of the design sector and the use of design in other sectors are major challenges laying ahead.
\end{abstract}

Keywords: creative industries; design; socio-economic development; creative clusters; 798 Art District; urban design and architecture; emerging economy; Beijing.

Reference to this paper should be made as follows: Van Tuijl, E. and Van der Borg, J. (2012) 'Designing the dragon or does the dragon design? An analysis of the impact of creative industries on urban development of Beijing', Int. J. Chinese Culture and Management, Vol. 3, No. 2, pp.125-138. 
Biographical notes: Erwin van Tuijl is a Researcher specialised in regional development and economic geography at the Erasmus University Rotterdam, The Netherlands. He is being involved in research activities at the Euricur of the Erasmus University since 2006. In his publications he focuses on the spatial dynamics of knowledge development and innovation by companies. He is also a lecturer in a number of bachelor's and master's courses at the Erasmus University.

Jan van der Borg is Professor of Economics of Tourism at the Ca' Foscari University, Italy and at the Erasmus University of Rotterdam, The Netherlands. $\mathrm{He}$ is also being involved in research activities at the Euricur of the Erasmus University since 1990s. For many years his research has been focusing on the economics of tourism, urban and local development, urban management and cultural heritage. He is also lecturer in various bachelor and master courses at the University of Venice and the Erasmus University.

\section{Introduction}

China is one of the oldest civilisations in the world and possesses a long history in art and culture. Although its material aspects have been neglected until recently, the country is very rich in cultural heritage: numerous palaces and temples dating many ages back. Art and culture have always played a major role in economic and social development.

Since the economic reforms in 1978, China has gradually opened to the world and has developed rapidly. The average annual growth of GDP between 1978 and 2005 was 9.6\% (Holz, 2008) and in terms of economic size it has recently become the second largest country in the world after the United States. Its share in global GDP growth since 2000 has been nearly twice as large as the next three other major emerging economies together (Brazil, Russia and India), and therefore, is also known as "the mother of emerging markets and transition economies" (Ordóñez de Pablos, 2007, p.1). However, China is still in the middle of a process of industrialisation, not yet needing to diversify its economic structure as urgently as Japan and many countries in Northern America and Western Europe. Remarkably, this has not hindered the city of Beijing to focus on culture and creativity as powerful means to revitalise and modernise parts of its urban economy. Moreover, it has already started to consider, although it still is competitive merely for its low production costs, the decisive role culture and design can play in moving upwards in the global value chain, towards activities that provide more added value.

Economic development has thus a number of important consequences for the development of creative industries in general and design in particular. First, due to rising income, especially in large cities such as Beijing and Shanghai, there is a rising demand for art ('aesthetical design') and new forms of art enter the Chinese market. Especially demand and supply of contemporary art, which was unknown in formal markets until the end of the 1990s, have risen quickly. This was one of the principal explanations of the growth of 798 Art District, one of the biggest clusters for contemporary art in China. Second, China's entrance in the WTO has led to increased political awareness for culture and creativity. In fact, culture was recognised as a fundamental ingredient of economic development and was quickly put on the political agenda in the period leading to the WTO accession (Keane, 2009). Officially, the creative industries became a priority of the state in the 11th Five Year Plan in 2005 (Rossister, 2008). An important goal within 
the 11th Fifth Year Plan is the ambition to change from 'Made in China' to 'Created in China', and thus to move China's industries upwards in the value chain. On the local level, creative industries got first attention in Shanghai in the beginning of 2004, while Beijing started the development of ten 'creative cultural' clusters slightly later in 2006 (Keane, 2009).

Another major event leading to an increased attention to and the development of design were the Beijing Summer Olympics in 2008. As in many other hosting cities, the Olympics were used as a flywheel for urban development, also by paying much attention to design of new iconic landmarks (e.g. the 'birds nest') and revitalisation of various areas in the city. Moreover, the Olympics have been used to increase awareness of development of a green society which has led to an increasing attention for the use of design for sustainable development.

This paper investigates the role of design in Beijing in all its aspects. We focus on the various types of design: design as an economic activity (and hence as part of the creative sector), design as an art form ('aesthetical design') and 'urban design'. We have investigated the success factors and barriers for design businesses in Beijing and show how design can be used by the socio-economic development of the city.

The material on which this paper is based was gathered during a visit to the city in May 2009. During this visit, 20 in-depth interviews were held with key-actors of Beijing's creative industry and with policymakers. ${ }^{1}$

The rest of this paper is structured as follows. Section 2 analyses the major geographical concentrations for design activities (with special attention to 798 Art District) and Section 3 describes the major success factors and barriers that influence the development of Beijing's design sector and other creative industries. The subsequent Section 4 deals with urban design, while the last Section 5 draws conclusions.

\section{Creative clusters in Beijing}

Most creative clusters in the Chinese capital can be found in the Chaoyang District, which has been designated as a development base for the creative industries. Hui (2006) distinguishes several important assets of the district to attract creative business. Firstly, the district functions as Beijing's new commercial centre with the Central Business District (CBD) and the Olympic Village as major locations providing several advantages for the creative industries. It has several urban amenities, such as bars, restaurants and theatres, which may attract the creative class (Florida, 2003). In addition, the CBD houses a large number of national and international headquarters and embassies which may increase demand for services from certain creative industries, such as media and advertising and the presence of (foreign) employees with high income incentives demand for cultural goods and services. Moreover, the CBD and Olympic area have several modern landmarks that enhance the district's image as modern city and might stimulate Chinese architects to focus on modern architecture. Secondly, the relocation of the CCTV, Beijing TV and Phoenix TV headquarters has increased the critical mass for the development of media industries. Thirdly, the district is home of various knowledge institutes that are specialised in certain creative industries, such as the Academy of Design of Tsinghua University and the Central Academy of Fine Arts (CAFA), which form a major basis for the development of the creative industries and might attract industries around them. Fourthly, various cultural festivals, like the 798 Art Festival, have been organised in order to enhance the image of Chaoyang as a creative district. 
There are (at least) two types of creative clusters in Chaoyang and in other districts in Beijing: 'artist' creative clusters and 'commercial' creative clusters. Artist creative clusters appear and grow 'spontaneously' by initiatives of artists who decide to concentrate in a certain area to benefit from Marshallian agglomeration economies (Marshall, 1920), such as a shared labour pool and unintended information spill-overs. Commercial creative clusters are driven by real estate speculations and are much more planned, focussing on commercial spinoffs of art and culture, and as a consequence increase land values.

In this section, we give characteristics of the two distinguished types of creative clusters based on an empirical analysis of 798 Art District and other creative districts.

\subsection{Art District}

798 Art District ${ }^{2}$ has transformed quickly from an artist cluster to a commercial cluster. This former state-owned electronics firm, that also produced equipment for the military industry, was set up with help of the communist regime in East Germany and was built in Bauhaus style. It started as an artist creative cluster by the spontaneous arrival of various artists and gallery owners that used empty spaces of the production site as galleries, working studios and meeting places. The plant was still largely in operation, but was targeted to be demolished in the near future. Meanwhile empty spaces were rent out to artists who benefited from low rents. The first artists settled down in the area in 2000-2002. They were attracted by low rent and the creative surrounding of the old production plant. The number of artist grew rapidly, since artists asked friends to come and created an informal community gathering at places such as in a bookshop. The first artist entered in 2000 and by the end of 2001 already 15 artists lived in the area. In 2002, Tokyo Gallery, under the name Beijing Tokyo Art Projects entered the factory, and in 2003 the district counted six galleries.

In 2006, the Beijing 798 Art Zone Administration and Development Office (in short 798 Management) was set up in order to serve as a bridge between tenants and the owner of the district, Seven Star Group. 798 Management and the local government decided not to demolish the plant and to focus on the exhibition and sales of contemporary art. Since that time, 798 Art District has grown rapidly, and in 2008 the district counted already 150 galleries. Moreover, the district increasingly receives international (media) attention through various articles published in foreign news papers and by visits of foreign policy makers.

The quick growth has also an important downside in the form of rising rents, and the district transformed rapidly from an artist creative cluster to a commercial creative cluster. The increasing rents push artists to other clusters and their studios were replaced by commercial galleries. Also, the audience has changed from real art 'freaks' to general tourists with limited knowledge about real art. In relation with this, real art disappears to make place for more commercial products. Moreover, the remaining production plants have closed down, while commercial galleries and secondary tourist products, such as hotels and restaurants are opened. This is considered as a major loss of the creative atmosphere in the identity of the area. Finally, there are tensions between 798 Management and tenants. For instance, there are doubts about the bridging role of the management between tenants and Seven Star Group, and it has even been argued that the management actually responds principally to Seven Star Group. 
The transition to a commercial creative cluster and a tourist attraction was speeded up by the Olympic Games. In January 2008, the district was appointed as an official spot for the Olympics and only a few weeks before the Olympics the area was upgraded intensively. Public art works were placed on the streets, public lightening was installed and green spaces were created in order to improve the urban landscape.

At the moment of writing, the district counts over 350 art institutes, which are active in different sectors: culture and art (140 institutes), design and consultancy (100 institutes), media (70-80) and tourism (bars and restaurants; 13). This diversity has been considered as an advantage since the various fields of design can reinforce each other and has potential synergies among the different fields. Nevertheless, nearly all our conversation partners agree that the district is too commercial. Similarly, Muynck (2009) states that 798 Art District destroyed the sources of creativity by its own success and that the art fabric changed to an art market. It should be mentioned that the role of real-estate speculation is common in creative industries in all parts of the world (Rossister, 2006) and many industries within the creative sector are characterised by tensions between cultural and commercial interests.

For the future development, the district has been targeted by 798 Management as a key area to show and sell Chinese temporary art. It is the major cluster that combines 'East with West' and the aim is to connect Beijing with the rest of the world in order to promote Chinese art. Currently, about $15 \%$ of the tenants come from abroad while $85 \%$ is Chinese. The ambition is to attract more famous foreign art companies, and to increase the total number of Chinese companies. Another ambition is to become a top tourist attraction just like the Summer Palace, although currently it is not considered by the municipality of Beijing as an official tourist attraction.

\subsection{Other creative clusters and a comparison with 798 Art district}

Creative clusters rise and fall and artists move from one cluster to the other in case of rising real estate prices or actions by policy makers. These spill-over effects are not necessarily bad, as long as the revitalisation of obsolete urban areas results to be sustainable. Beijing has numerous creative clusters that rise and fall quickly. Two of the first creative clusters in Beijing were Yuanmingyuan, near the old ruins of the old Summer Palace, and Dong Cun. Both districts were artist creative clusters, spontaneously developed by the artists themselves, enjoying the creative surrounding away from the city centre and the policy makers. This was important, since until the end of the 1990's, art was under strict censorship (Rui, 2008). Nevertheless, in 1994 as compared to 1995 the clusters were forbidden by the government and the police raided the artists (Pasterneck, 2008). Nowadays, there are several creative clusters, including both artist creative clusters arisen on new locations where artists have settled down as well as commercial creative clusters often stimulated by the government which use creative clusters as a new policy tool to realise economic growth. Initially, and in contrast to Shanghai, which directly opted for setting up numerous creative clusters, the Beijing government focussed on ten creative clusters. However, in 2008, probably also due to the Olympics, this number has risen quickly (Keane, 2009). The major creative clusters are summarised in Table 1.

There are numerous important differences between 798 Art District and the other districts. Firstly, most other districts are relatively new and started considerably later than the 798 Art District. Secondly, whereas the 798 Art District today serves mainly as a place to sell and show art, many of the other districts consist of studios and galleries and 
function thus as centres of production. Moreover, most other districts have lower rents and form a more inspiring surrounding for artists due to the lack of many tourists. It has been argued that 798 Art District and the other districts are complementary to each other where 798 Art District serves as the commercial and tourist hub to sell and show Chinese contemporary art, while the others function as production centres producing art works that are sold in 798 Art District. This might be promising especially since 798 Art District is already a strong brand. However, as noted before, it is argued that 798 Art District sells more commercial art and art lovers do not go to 798 Art District. Moreover, Keane (2009) argues that creative clusters in China are developed by real estate developers in cooperation with the local government focussing on rising real estate prices. It might happen that other creative clusters may also develop from artist creative clusters to commercial creative clusters as it has happened in 798 Art District, and as it has been feared in the Hutong cluster.

Table 1 Creative clusters in Beijing

\begin{tabular}{|c|c|c|}
\hline Cluster & Focus & Characteristics \\
\hline D-Park & $\begin{array}{l}\text { Fashion design and } \\
\text { architecture }\end{array}$ & $\begin{array}{l}\text { Mixed perceptions: Less } \\
\text { commercial and more creative } \\
\text { atmosphere than } 798 \text { versus } \\
\text { tourist attraction by the } \\
\text { restoration of an old plant in } \\
\text { original style } \\
\text { Located next to } 798\end{array}$ \\
\hline Songzhuang Art Village & $\begin{array}{l}\text { Production of temporary art } \\
\text { that is directly sold to the } \\
\text { international art market }\end{array}$ & $\begin{array}{l}\text { Large artist community with } \\
\text { over } 1000 \text { artists and several } \\
\text { galleries }\end{array}$ \\
\hline Huantie Art District & $\begin{array}{l}\text { Place where artists live and } \\
\text { work }\end{array}$ & $\begin{array}{l}\text { Former storage site for railway } \\
\text { goods located in railway testing } \\
\text { track } \\
\text { Creative and calm atmosphere }\end{array}$ \\
\hline $\begin{array}{l}\text { Chao Chang Di Art } \\
\text { Village }\end{array}$ & Production and sales of art & $\begin{array}{l}\text { Set up by local government } \\
\text { Counts currently } 20 \text { galleries }\end{array}$ \\
\hline Jiuchang Art District & Art and graphical design & $\begin{array}{l}\text { Next to the Central Academy of } \\
\text { Fine Arts } \\
\text { Professors with own galleries } \\
\text { Houses the core development } \\
\text { centre for the Chinese cartoon } \\
\text { industry }\end{array}$ \\
\hline $\begin{array}{l}\text { Suojiacun, Feijiacun and } \\
\text { Art Base I }\end{array}$ & Mainly art studios & $\begin{array}{l}\text { Low rents } \\
\text { Quite and inspiring surrounding }\end{array}$ \\
\hline Cable 8 & $\begin{array}{l}\text { New media and other creative } \\
\text { industries }\end{array}$ & $\begin{array}{l}\text { Old electric cable factory } \\
\text { Houses currently } 160 \text { companies }\end{array}$ \\
\hline $\begin{array}{l}\text { 'Hutong cluster' (Ban Qiao } \\
\text { Hutong and Dong Si } \\
\text { Hutong) }\end{array}$ & $\begin{array}{l}\text { Architecture and other } \\
\text { creative industries }\end{array}$ & $\begin{array}{l}\text { Ancient neighbourhoods in } \\
\text { central Beijing } \\
\text { Vibrant atmosphere } \\
\text { Low rents } \\
\text { Proximity public transport }\end{array}$ \\
\hline
\end{tabular}


Based on the development of 798 Art District and the other clusters we have identified the major characteristics of the two types of creative clusters, as summarised in Table 2. Note that the clusters described in this section are not the only creative clusters in Beijing. There are much more creative clusters focusing on various types of creative industries, such as China (Huarou) Movie and TV Industry Zone and China New Media Industry Base.

Table 2 Characteristics of artist and commercial creative clusters

\begin{tabular}{|c|c|c|}
\hline & Artist & Commercial \\
\hline Focus & Aesthetical value of art & $\begin{array}{l}\text { Commercial value by rising real } \\
\text { estate prices }\end{array}$ \\
\hline Function & $\begin{array}{l}\text { Design/production of art: artist } \\
\text { studios }\end{array}$ & $\begin{array}{l}\text { Sales and tourism: galleries and } \\
\text { exhibitions of arts }+ \text { secondary } \\
\text { tourism products }\end{array}$ \\
\hline Initiative takers & Artists and entrepreneurs & $\begin{array}{l}\text { Cluster managers on behalf of land } \\
\text { owners }\end{array}$ \\
\hline Customers & Art lovers & (Mass) tourists \\
\hline Products & Art & 'Cheap/commercial art' \\
\hline \multirow{3}{*}{$\begin{array}{l}\text { Other } \\
\text { characteristics }\end{array}$} & Low real estate prices & High real estate prices \\
\hline & $\begin{array}{l}\text { 'Creative atmosphere' informal } \\
\text { gatherings and networks, 'buzz' }\end{array}$ & $\begin{array}{l}\text { Direct or indirect control district } \\
\text { government }\end{array}$ \\
\hline & $\begin{array}{l}\text { 'Untouched old places' (e.g. old } \\
\text { production plants, railway storage } \\
\text { buildings) }\end{array}$ & Upgraded areas \\
\hline
\end{tabular}

\section{Success factors and barriers for the development of Beijing's creative industries}

Creative and cultural industries are relatively new in China, and were set on the political agenda in 2005 only. One year later the City of Beijing explicitly paid attention to it. Also, a recent survey of Zhao (2009) shows that Beijing's creative industries are still in an early stage of development. Nevertheless, the creative industries have risen quickly. In 2005, the cultural, sports and entertainment industries counted 215,000 jobs, which is equal to $3 \%$ of the total workforce (City of Beijing, 2006). The city has a wide variety of creative industries, such as movie production, fashion, art and architecture. All these creative industries are spatially concentrated in large clusters, despite the fact that the creative industries are relatively young. For instance, China (Huarou) Movie and TV Industry Zone covers $5.6 \mathrm{~km}^{2}$ and it has 1560 companies.

Beijing has some competitive advantages for the development of creative industries compared to other Chinese cities. As cultural and political capital of China, it has a sufficient critical mass and economic diversity. Many of the people that were interviewed underlined the fact that one of the principal assets of Beijing is that it is China's capital. The proximity of the state government has some advantages for the development of creative industries due to fast decision making and implementation of plans and access to financial resources. Its status as a capital city and due to political power (Chen, 2008) it 
has attracted numerous (inter)national headquarters and several urban amenities, creating the right variety and a metropolitan ambiance that might attract the creative class. Moreover, the capital attracts higher income groups. The presence of higher income groups is important for cities, since these are the major target groups for art. In relation with this, the city's fast economic growth and the rising incomes have led to a growing art market. Especially, contemporary art - which is relatively new in China - and fashion markets have grown rapidly. In addition, China's ambition to move up in the value chain by shifting the focus from mere production to creation (design) and production offers huge potential for the design sector in Beijing.

Another crucial factor to develop creative industries and to move up in the value chain is a good knowledge infrastructure. Beijing has several universities, public and private research centres and educational facilities. The city has at least two institutes specialised in creative industries that are among the best in China: the CAFA and Tsinghua University, which includes a top school in architecture and planning. Beijing also attracts many foreign educational institutes. For instance, a branch office of Columbia University intends to locate in the Hutong cluster, which is seen as a particularly attractive location because of its inspiring surroundings. Besides specialised research schools and training centres, there are also other ways to increase the knowledge level in a region. Firstly, companies can improve the labour pool and attract talent. Especially foreign companies can play a major role in this, since these companies have a longer tradition in contemporary art and design, which is still relatively new for many Chinese companies. The perceptions about this are mixed. We have seen examples of foreign companies that provide several activities - like supply of internships, provision of guest lectures and organisation of summer schools - to train students and improve local education institutes. However, during the interviews it was also argued that especially famous design companies could do more to transfer their knowledge to local actors instead of doing only big projects. Secondly, Chinese companies can increase their knowledge level via foreign study trips and cooperation with foreign partners. A third way to gain knowledge is via students and workers who studied or worked abroad and return to China in order to set up their own design school or to start their own companies. For instance, the Design School of the University of Art and Design in Helsinki attracts many Chinese students (from bachelor to $\mathrm{PhD}$ level) who return to China to work as designer after receiving their degree.

There are also some major, often related, barriers that may hinder development of creative industries and upward movement in the value chain. A first barrier is that, in general, the focus is still on production or duplication of original products. There are various reasons for this. First, the shift in focus takes time since there is a need to change skills which requires changes in the training and the education system. Second, design and engineering are considered as equal, and the lack of a distinction among the two disciplines makes it difficult to focus on design. Third, there is a tension between originality and creativity which may hinder upgrading. For instance, Keane (2009) argues that the lack of content in China's animation industry forces business to fall back on manufacturing. Similarly, Van Winden et al. (2010) argue for China's automotive industry that since production is still profitable, the need to make the decisive shift to higher added-value activities is limited. In a similar way, many media industries imitate global successes in order to make profit and because financing, producing and 
distributing of original content is difficult (Keane, 2006). It is very likely that this is also the case in other sectors, although there are positive exceptions of both foreign as well as Chinese galleries that want to highlight the cultural aspects of art instead of commercial aspects.

Nevertheless, and as a second development barrier, gallery holders, artists and other art institutes are confronted with the paradox between the desire to do non-commercial activities focussing on cultural value of art and the need to focus on commercial activities in order to survive. As noted before, this paradox is a common characteristic in many creative industries in all places of the world. A difference between China and many Western countries, however, is the lack of a public system of financial incentives that help non-commercial activities to survive and to stimulate creativity in general.

A third development barrier is the low level of the education system. In spite of the presence of key knowledge institutes and strategic actions of firms to improve the knowledge base, the poor level of the education system has been perceived as a major drawback for further upgrading and development of the creative industries. All our interview partners agree that the educational level is low and that there is a need to change the education system. Art education has already changed. In the past, art education was limited to teaching classical Chinese art with silk and ink as major specialities, and the focus was on socialist realism. In a later stage, also the European Expressionism and Impressionism had been added in the educational programme. Nowadays, education has been more updated with more influences from outside China and pupils have more freedom than in the past. Nevertheless, the education system is still very hierarchical and students are expected to listen to the teacher, leaving little room to express own ideas and to develop creativity. As a consequence, many designers lack own ideas and originality. Mars (2009) notes the same and states that there is an absence of good designers due to a lack of good design education. The already mentioned focus on commercial values, which increases the tendency to copy products, is also a major barrier in the education system. From our interviews it has become clear that in the education system the focus is still in developing skills to sell art instead of creating it. Moreover, it was also argued that Chinese students who return from abroad face problems in applying their obtained knowledge as they need to focus on the commercial value of art, although they are aware of the aesthetical value. So, there is a need to embed creative processes in the education system, to get rid of the idea that quantity of production equals to economic value (Keane, 2006) and to pay more attention to aesthetical values of art.

A final development barrier we have found is that there is too much bureaucracy. For instance, galleries need to ask permission and pay a fee for holding an exhibition at least three months in advance. Furthermore, there are many limitations for the works shown, and the government has an influence on what can be shown. It should be noted that there are also art forms permitted in China which are not common and prohibited in the west for ethical reasons, like death bodies and animals. Similarly, also architects face regulations as barriers that hinder creative freedom and work. It was argued that during the design process many new requirements and limitations have been given, which leads to many adaptations of the ongoing project, and in the end many ideas of the first idea disappeared. However, some interview partners do not agree and argue that it is possible to make clear agreements to safeguard architectural quality at the beginning of the design process. The different views might be explained by the role of the different players in the 
design process. Actors which focus on aesthetical aspects of architecture might have more reasons to complain than other actors. It should be pointed out, that architecture in general, in all parts of the world, has been confronted with more safety and environmental regulations that limit creativity.

\section{Urban design}

Design plays a major role in urban development in various fields. First, urban design (including architecture and landscape design) is crucial for physical development of the city. Design also plays a role in social development, development of infrastructure and in sustainable development (e.g. reduction of air pollution). In this section, we analyse the role of design in these fields in more detail.

Architecture plays a key role in the physical and symbolic development of a city. Since the Cultural Revolution, architecture in Beijing has evolved in three stages (see Table 3). In the first stage, after the Cultural Revolution, the focus was on building a modern city with ancient Chinese aspects. The second stage, leading to the Summer Olympics is characterised by the introduction of modern Western design, boosted by the invitation of Western 'starchitects' to design new landmarks in the Chinese capital. After the Olympics, in the third stage, the state stopped the attention on foreign architecture, and in the current period, there is the belief that China can design modern architecture without foreign support. Some Chinese architects have even entered international markets, with MAD's Toronto Towers as best practice up to now. The major shift in focus in this period is caused by a change in priorities of the state. China succeeded in designing safe and more sustainable buildings, but it still needs to make progress in creating buildings taking into account a safe and clean environment. There are also doubts about the quality of Chinese architecture design, as there are questions about the quality of the design consultants in various stages. Moreover, there are doubts about the export opportunities for Chinese architects. It has been feared that many low quality architects will enter the international market after the success of MAD in Toronto. Furthermore, it has been argued that MAD won the project in Toronto also because of the experience of the European designers who worked for the company in that time. Other Chinese firms may lack foreign experience and knowledge.

Culture and cultural heritage have also played a major role in the development of Beijing. Beijing was set up along a vertical axis according to Confucius' believes (Tan, 2005). Nowadays, this vertical axis is still the major central line of the city, and most cultural attractions are located along this axis that runs from the Olympic Green in the north to Temple of Heaven in the south. Culture is a cause of various periods in architecture and influences cultural heritage. About 20 years ago, the government did not pay attention to cultural heritage for economic and cultural reasons. First, due to low labour costs it is more efficient to demolish old sites and to construct new buildings from scratch than to renovate buildings and sites. A second reason is related with culture. One aspect of the change of dynasty, the turn to another period, is to forget the previous period and to build new elements. There is in this ideology no reason to keep elements from previous periods. Foreign as well as local architects pointed at the importance of keeping old heritage, and nowadays also the Chinese government realises that certain parts of the past need to be conserved, also for economic motives. 
Table 3 Stages in Beijing's architectural development after the Cultural Revolution

\begin{tabular}{|c|c|c|c|}
\hline Stage & Period & Focus & Characteristics \\
\hline \multirow[t]{2}{*}{1} & $1970-1990$ & Build a new and modern city & $\begin{array}{l}\text { Construction of low-quality } \\
\text { skyscrapers, with ancient roofs }\end{array}$ \\
\hline & & & Deconstruction cultural heritage \\
\hline 2 & 1990-2008 & $\begin{array}{l}\text { Modernisation of the city by } \\
\text { Western design, leading up to } \\
\text { the Olympic games }\end{array}$ & $\begin{array}{l}\text { Invitation of (famous) Western } \\
\text { designers to design modern land } \\
\text { marks (e.g. CCTV tower of Koolhaas } \\
\text { or the Olympic stadium by Herzog } \\
\text { and de Meuron) }\end{array}$ \\
\hline 3 & $>2008$ & $\begin{array}{l}\text { Shift from aesthetical aspects of } \\
\text { buildings to functionality and } \\
\text { attention to design in } \\
\text { environmental friendly way }\end{array}$ & $\begin{array}{l}\text { Mixture of Western and Chinese } \\
\text { design }\end{array}$ \\
\hline
\end{tabular}

Design plays also a major role in sustainable development and in the reordering of public space, which gained both particular attention in Beijing in the preparation for the Olympic Games. Just like in many other cities that hosted the Olympics in the past, Beijing did not only use the Olympics to get media attention but also to build landmarks. The mega event has also been used for urban development and to promote and apply sustainability. Various districts in the city, such as 798 Art District, were regenerated and improved to receive visitors. Moreover, the event played a key role in increasing the awareness of sustainability and the environment among the public. Many actions that were taken for the Olympics, aiming at stimulating liveability and sustainability, continue after the games. One example is the 'one-day-drive-less programme' in which car owners are required to drive one day a week less. This is absolutely necessary, since car ownership rises quickly, with about 1000 new registered cars per day. The Olympic venues themselves are also important to realise a green city. The venues are constructed with environmental friendly materials, and buildings are designed in such a way that the amount of incoming natural light has been maximised in order to save energy. Thus, in this sense, urban design plays a key role in developing the city in a sustainable way and to bring the city in harmony. After the Olympics, there is still awareness and willingness among policy makers and society to develop a green city, but there is also awareness that there is still a long way to go to do that.

Furthermore, design plays a key role in development of tourism and in social development. Firstly, modern architecture and attractions, such as Olympic venues, could be used to diversify the tourist product and to attract new target groups which are also interested in modern attractions. However, currently, the follow-up of the Olympics faces problems as many Olympic attractions and spaces are seen as a burden rather than an asset. Secondly, design has been used to solve practical problems due to peaks in the tourism flow creating pressure on facilities. For instance, on Labour Day, the busiest day of the year, over 120,000 visitors visit the Forbidden City. Practical tools that have been used in the Forbidden City include: signposting in one direction and an extension of the number of employees who protect the attractions. Besides these and other practical solutions, in which design plays a key role, the city also uses other measures to fight the peaks in tourism flow, such as the use of price differentiation. Thirdly, design has been used to conserve and to upgrade traditional areas that are targeted as tourist attractions, such as certain selected hutongs. Hutongs are old Chinese neighbourhoods with small houses and narrow streets, often characterised by low living conditions due to the small size and limited basic facilities, such as fresh water, and a proper sewage system. After 
the Cultural Revolution, many hutongs were replaced by new flats, built by state designers, or at least according to standards given by the state. There seems to be a tension between the urban and social structure of the old hutongs and modern (sub)urban areas. On the one hand, the new apartments have a higher quality and better living standards (larger size, and modern facilities) than the hutongs, but on the other hand they lack the common spaces that fulfilled social functions. It seems to be impossible to keep the urban and social structure in the new flats. However, nowadays, various foreign as well as domestic design companies have designed conceptual plans for old hutong areas that mix various functions, such as tourism, culture and retail and aim to conserve public spaces as far as possible.

Another field where design plays a role is (public) transport. In order to fight congestion, the subway network has been extended extensively and will be further extended from $260 \mathrm{~km}$ nowadays to $560 \mathrm{~km}$ in 2015 . Also, the quality of the lines and the stations has been improved, because of another contracting system. In the past, station and subway development was done by a special institute and design played only a limited role. Nowadays, there are open competitions to design and develop new plans. This has increased the quality and stations have a higher aesthetical value. A major drawback, however, is the lack of adaptive design of the subway system. The system is based on applications that have been developed for the use in Hong Kong and in Shanghai, without the adaptive development to local usage which has led to practical problems. Another major drawback is that Beijing is developing itself as a car-oriented city, which increases congestion and pollution. Cars are seen as status symbols and the idea is that an increased road transport leads to further leaps in economic development. Therefore, roads have been broadened, while the space for pedestrians and cyclists continues to decline.

\section{Conclusion}

This paper shows first of all that the emphasis laid on the role that the creative industry can play for socio-economic development and for urban revitalisation is not exclusively reserved to post-industrial economies and cities. In fact, from 2005 onwards, the development of cultural clusters has been one of the priorities of the Beijing administration and it is investing in design as a form of art and in urban design. This last aspect is speeded up by the fact that the city hosted the Olympic Games 2008 for which many public spaces have been improved. In that occasion, a large number of modern iconic buildings have been added to Beijing's skyline.

Less relevant is the role that industrial design and creativity can play in upgrading the Chinese manufacturing sector. Much of the competitiveness of the Chinese industry is still based on the low factor costs, in particular that of labour and land. Moreover, simply copying successful concepts from American, European or Japanese firms is still widespread and beneficial. The awareness that this comparative advantage may not last indefinitely, has already led to a shift in the focus and a search to move upward in the global value chain, engaging in higher value-added activities. Therefore, the government has started to underline the importance of defending more intensively the property rights or the intellectual components in manufacturing.

The principle asset of Beijing is the fact that it is the capital of China. The presence of the national government is very strong, and therefore, financial resources to make the city as attractive as possible are available. Its status as a capital city attracts also 
numerous headquarters of national and international firms, as well as providing it with facilities that can not be found in other cities. Hence, it offers the right variety and a metropolitan ambience that may attract the creative class. Moreover, the large number of headquarters and embassies in the city may increase demand for services from certain creative industries, such as media and advertising, and the presence of (foreign) employees with high income incentives demand for cultural goods and services. In addition, Beijing has a long tradition in both aesthetical as well as urban design, but pays also increasingly attention to modernity and contemporary arts. The particular mixture of traditions and modernity is now seen as Beijing's potential selling points, but it is a challenge to transform these aspects in one unique (tourist) product.

A growing awareness for sustainable development and willingness to invest in it offers major opportunities for the growth of the design sector. Moreover, growth in the average income per head of the population has caused the market for arts and designs to expand, an expansion that is expected to continue the coming decade. Finally, the desire to move upwards in the global value chain, shifting gradually from a low cost concept to a high contents and value added idea of manufacturing, will offer huge opportunities for industrial designers.

In order to use these potentials fully, some important barriers have to be removed. First of all, the education system has to be changed, gradually teaching students to become more critical and autonomous. This is, given the present political system where individuality is not much appreciated, not as easy as it may sound. Second, more value should be attributed to originality and less to duplication. At the moment, the market does not attribute enough commercial value to originality and hence copying continues to be a winning strategy. This makes Chinese architects and other designers vulnerable to international competition. The existing creative clusters in Beijing are under pressure because of their own success. Land rents are rising and the market forces artists to focus either on commercial activities or leave the cluster in search of cheaper accommodation. Another hindrance for the further development of Beijing's creative industries is the weight of bureaucracy and in some cases of censorship. The tension between spontaneity and grassroots development and planning and intervention, that also characterises Western creative clusters, is definitively penalising creative industries in China and Beijing.

\section{Acknowledgements}

This research has been supported financially by the Institute for Housing and Urban Development Studies (IHS) at Erasmus University in Rotterdam. The authors want to thank Alessandro Costa and Eugenia Murialdo for their support during the field work in Beijing. The authors would also like to thank Gert-Jan Hospers for his comments on earlier versions of this paper. Of course, the responsibility of the contents of this paper is of the authors alone.

\section{References}

Chen, Y.C. (2008) 'Why do multinational corporations locate their advanced R\&D centres in Beijing?', Journal of Development Studies, Vol. 44, No. 5, pp.622-644.

City of Beijing (2006) Beijing Statistical Yearbook 2006. Available online at: http://www.bjstats. gov.cn/tjnj/2006-tjnj/index-english.htm

Florida, R. (2003) The Rise of the Creative Class, Basic Books, New York. 
Holz, A.H. (2008) 'China's economic growth 1978-2025: what we know today about China's economic growth tomorrow', World Development, Vol. 36, No. 10, pp.1655-1691.

Hui, D. (2006) 'From cultural to creative industries - strategies for Chaoyang District Beijing', International Journal of Cultural Studies, Vol. 9, No. 3, pp.371-331.

Keane, M. (2006) 'From made in China to created in China', International Journal of Cultural Studies, Vol. 9, No. 3, pp.285-296.

Keane, M. (2009) 'Great adaptations: China's creative clusters and the new social contract', Continuum: Journal of Media and Cultural Studies, Vol. 23, No. 2, pp.221-230.

Lei, C. and Qi, Z. (2008) Beijing 798 Now, Timezone 8, Beijing.

Mars, N. (2009) 'How to produce good architects?', Urban China, No. 35, January.

Marshall, A. (1920) Principles of Economics, MacMillan, London.

Ordóñez de Pablos (2007) 'Foreword for a special issue on China today: reality and challenges', International Journal of Chinese Culture and Management, Vol. 1, No. 1, pp.1-3.

Pasterneck, A. (2008) 'Other kinds of ambitions: from artist villages to art districts', Urban China, No. 33.

Rossister, N. (2006) 'Creative industries in Beijing: initial thoughts', LEONARDO, Vol. 39, No. 4, pp.367-370.

Rossister, N. (2008) 'Countermapping creative industries in Beijing (introduction)', Urban China, No. 33, December.

Rui, H. (2008) Reflections on 'Factory' of Art - Beijing 798, Sichuan Fine Arts Publishing House, Chengdu.

Tan, L. (2005) 'Revolutionary spaces in globalization: Beijing's Dashanzi Arts District', Hybrid Entities Intersections Conference Journal - Graduate Student Conference of Ryerson/York University, 18-20 March, Toronto, Canada.

Van der Borg, J. and Van Tuijl, E. (2010) Design Cities: Design as a Fundamental Input for the Urban Knowledge Economy, Euricur, Rotterdam.

Van Winden, W., van den Berg, L., Carvalho, L. and van Tuijl, E. (2010) The Role of Manufacturing in the New Urban Economy, Routledge, Abingdon, Oxford.

Zhao, J. (2009) 'A survey on Beijing's cultural creative industries', International Journal of Chinese Culture and Management, Vol. 2, No. 2, pp.146-166.

\section{Notes}

1 See Van der Borg and Van Tuijl (2010) for details.

2 This section is based on interview data and Lei and Qi (2008) and Rui (2008). 